Tersedia online di:http://ejournal-balitbang.kkp.go.id/index.php/jkpi
e-mail:jkpi.puslitbangkan@gmail.com
JURNAL KEBIJAKANPERIKANANINDONESIA
Volume 10 Nomor 2 November 2018
p-ISSN: 1979-6366
e-ISSN: 2502-6550
Nomor Akreditasi Kementerian RISTEKDIKTI: 21/E/KPT/2018

\title{
STRATEGI DAN KEBIJAKAN PRODUKSI PADA BUDIDAYA IKAN NILA
} BERDAYA SAING

\section{STRATEGY AND POLICY ON PRODUCTION OF COMPETITIVE TILAPIA AQUACULTURE}

 \\ Wartono Hadie ${ }^{1}$ \\ Pusat Riset Perikanan, Gedung BRSDMKP II, JI. Pasir Putih II, Ancol Timur, Jakarta Utara-14430, Indonesia \\ Teregistrasi I tanggal: 05 April 2018; Diterima setelah perbaikan tanggal: 31 Juli 2018; \\ Disetujui terbit tanggal: 07 Agustus 2018
}

\begin{abstract}
ABSTRAK
Kontribusi perikanan budidaya termasuk ikan nila terhadap ekonomi perikanan dan ekonomi nasional, menunjukkan nilai strategis dengan Nilai Tukar Pembudidaya Ikan mencapai 99,72. Khususnya kontribusi komoditas nila mencapai 30,72 \% dari total produksi ikan bersirip nasional tahun 2015. Hasil analisis menunjukkan bahwa strategi jangka pendek yang diperlukan adalah penerapan tehnik budidaya yang efisien pada komoditas nila unggul merupakan kebutuhan mendesak untuk mencapai produktivitas yang kompetitif. Strategi jangka menengah yang perlu dipertimbangkan adalah pemanfaatan tambak darat untuk budidaya nila sebagai upaya perluasan lahan budidaya selain kolam dan karamba jaring apung yang telah eksis. Kebutuhan induk unggul nila dapat diproduksi secara massal melalui beberapa brodstock center milik pemerintah maupun perusahaan swasta yang telah beroperasi. Antisipasi kebijakan dalam merespon Inpres No.7 Tahun 2016 adalah pengembangan industri pakan ikan skala kecil dan pemanfaatan induk unggul dalam perspektif pertumbuhan dan perluasan yang mencakup dua aspek kebijakan sebagai berikut : (a) Pengembangan produksi berbasis potensi pasar yang dikomplemen dengan perbaikan sistem budidaya ikan, dan (b) Pengembangan inovasi kelembagaan dan sistem insentif dalam mendukung ketersediaan dan akses sarana produksi utama pada usaha budidaya nila skala kecil.
\end{abstract}

Kata Kunci: budidaya nila; daya saing; kebijakan; produksi; strategi

\begin{abstract}
The contribution of aquaculture including tilapia to fishery economy and national economy shows strategic value with Fisheries Term of Trade reaching 99.72. Especially the contribution of tilapia commodities reaches $30.72 \%$ of the total national finned fish production in 2015.Result of the analysis showed that application of efficient cultivation techniques to superior tilapia commodities is a short-term strategy to achieve competitive productivity. The medium-term strategy is the use of terrestrial ponds for tilapia cultivation as an effort to expand cultivation land in addition to ponds and floating net cages that already exist. The needs of superior tilapia parents can be mass produced through several government broodstock centers and private companies that have been operating. Anticipation of policies in responding to Presidential Decree No.7 of 2016 is the development of small-scale fish feed industry and utilization of superior broodstock in the perspective of growth and expansion which includes two aspects of policy as follows : (a) Development of market-based potential production that is complemented by improved fish farming systems; and (b) Development of institutional innovations and incentive systems in support of availability and access to key production facilities on small-scale tilapia aquaculture.
\end{abstract}

Keywords: Competitiveness; production; policy; strategy; tilapia culture 


\section{PENDAHULUAN}

Kontribusi perikanan budidaya termasuk ikan nila terhadap ekonomi perikanan dan ekonomi nasional menunjukkan nilai strategis. Nilai strategis komoditas nila dapat diketahui melalui nilai tukar pembudidaya yang dihitung dengan indeks harga yang diterima (pendapatan) dan indeks harga yang dibayar (pengeluaran rumah tangga). Agregat pendapatan tersebut setelah dilakukan indeksasi kemudian menjadi indeks harga yang diterima. Agregat pengeluaran rumah tangga untuk pengeluaran usaha, konsumsi dan pegeluaran lain merupakan indeks harga yang dibayar rumah tangga. Rasio antara indeks harga yang diterima dengan indeks yang dibayarkan adalah indeks Nilai Tukar Pembudidaya. Nilai Tukar Pembudidaya Ikan mencapai 99,72 khususnya kontribusi komoditas nila mencapai $30,72 \%$ dari total produksi ikan bersirip nasional tahun 2015 (Pusat Data Statistik dan Informasi, 2016).

Dalam rangka percepatan pembangunan industri perikanan nasional guna meningkatkan kesejahteraan masyarakat baik nelayan, pembudidaya, pengolah maupun pemasar hasil perikanan, meningkatkan penyerapan tenaga kerja dan meningkatkan devisa negara, Presiden RI mengeluarkan instruksi presiden no. 7 tahun 2016 tentang percepatan pembangunan industri perikanan nasional. Sehubungan dengan instruksi tersebut, KKP telah menetapkan 50 lokasi sentra budidaya dengan limakomoditas utama diantaranya adalah ikan nila (KKP, 2015; Pusat Data, 2016).

Komoditas ikan nila menjadi salah satu komoditas utama dalam pembangunan perikanan budidaya dan ditargetkan dapat mendorong tercapainya program industrialisasi perikanan. Ketetapan tersebut didasarkan atas posisi Indonesia sebagai eksportir ikan nila pada peringkat ke dua setelah Cina. Kebutuhan nila dalam bentuk fillet di pasar Amerika cukup besar, dan pasar potensial lainnya untuk nila adalah Uni Eropa, Iran dan Rusia (Fitzsimmons, 2012; FAO, 2017).

Berkaitan dengan Peraturan Menteri Kelautan dan Perikanan No. 25 Tahun 2015 tentang Recana Strategis Kementerian Kelautan dan Perikanan, maka diperlukan adanya kajian terkait dengan budidaya ikan nila yang akan mendukung keberhasilan program industri perikanan (KKP, 2015; Bappenas, 2016).

Tulisan ini bertujuan untuk menganalisis strategi pengembangan budidaya ikan nila berdaya saing dengan pendekatan analisis Strength, Weaknesses,
Opportunities, and Threath (SWOT). Diharapkan, melalui hasil analisis yang dilakukan dapat memberikan masukan bagi pemerintah dalam meningkatkan produksi ikan nila yang memiliki daya saing tinggi.

Penelitian dilakukan dengan metode rapid rural appraisaluntuk memperoleh informasi dengan cepat, akurat dan mendalam (Townsley, 1996; Mulyaningrum, 2108). Data primer diperoleh melalui survei lapang, wawancara secara mendalam (in-depth interview) dengan stake holder dan responden kunci. Data sekunder diperoleh dari literatur dan laporan tahunan dari instansi terkait. Responden dipilih dengan menggunakan metode purposive sampling

Metode analisis data yang digunakan dalam penelitian ini adalah analisis SWOT, yaitu suatu analisis yang mengidentifikasi berbagai faktor secara sistematis untuk merumuskan suatu strategi tertentu (Rangkuti, 2008). Analisis ini berdasarkan logika yang dapat memaksimalkan kekuatan (strength) dan peluang (opportunities), serta meminimalkan kelemahan (weaknesses) dan ancaman (threats).

Survei dilaksanakan pada periode Maret - April 2017 di provinsi Lombok Tengah, dan DI Yogyakarta, serta November 2017 di Jawa Barat.

\section{BAHASAN}

Strategi pengembangan budidaya nila dilakukan dengan pendekatan SWOT. Faktor lingkungan internal dan eksternal yang dihadapi dalam pengembangan budidaya nila perlu dipertimbangkan dalam analisis SWOT. Data yang diperoleh dianalisis dengan membandingkan antara faktor eksternal peluang dan ancaman dengan faktor internal kekuatan dan kelemahan, sehingga dari analisis tersebut dapat diambil suatu keputusan strategi dalam pengembangan budidaya nila yang berdaya saing (Rangkuti, 2008; Marimin, 2004).

Budidaya nila pada taraf nasional masih memerlukan dukungan kebijakan yang strategis karena daya saing yang belum optimal, sehingga dibutuhkan pemikiran peningkatan daya saing untuk mendorong komoditas nila menjadi andalan dalam industrialisasi perikanan.

Kerangka pikir analisis pengembangan budidaya ikan nila berdaya saing dapat dilihat pada Gambar 1 . 




Gambar 1. Kerangka pikir analisis pengembangan budidaya ikan nila berdaya saing.

Figure 1. Framework on the analysis of competitive culture for tilapia.

\section{Kinerja Perbenihan dan Pakan Ikan Nila}

Analisis deskriptif terkait dengan pemanfaatan induk dan benih unggul ikan nila yaitu beberapa jenis ikan nila intoduksi yang telah di rilis oleh Menteri Kelautan dan Perikanan. Beberapa strain yang telah di rilis antara lain nila Nirwana, nila Srikandi, nila BEST, nila Larasati, nila Jatimbulan, dan semua strain ini merupakan hasil pemuliaan.Jumlah strain unggul nila sudah cukup banyak, namun saat ini kondisi induk dan benih unggul ikan nila masih dalam tahap pengembangan sistem perbenihan yang terbatas. Artinya kontribusi peran pemerintah masih dominan, dan pihak stake holder maupun komersialisasi oleh pihak swasta belum terlihat secara signifikan. KKP terus memacu pengembangan sistem perbenihan melalui pemberlakuan sistem jaminan mutu terhadap semua fungsi sistem perbenihan perikanan nasional yang di implementasikan dalam bentuk regulasi yaitu sertifikasi Cara Pembenihan Ikan yang Baik (CPIB). Ketersediaan induk dan benih berbagai strain nila unggul yang telah berkembang di masyarakat relatif terbatas, hanya beberapa strain yang masih eksis. Salah satu strain yang telah tersebar luas adalah nila Nirwana III dan sudah di rilis pada tahun 2016 melalui keputusan No. 28/KEPMEN KP/2016. Distribusi nila Nirwana telah mencapai 16 provinsi, namun produk yang di kirim masih berupa calon induk nila. Strain nila Srikandi juga telah mulai berkembang di masyarakat dan telah di rilis pada tahun 2012 . Distribusi nila Srikandi masih terbatas pada beberapa provinsi, hal ini disebabkan oleh regulasi institusi riset yang hanya menghasilkan strain unggul dan tidak memiliki mandat untuk mendistribusikan secara langsung kepada masyarakat. Strain nila Srikandi sebenarnya memiliki potensi untuk dikembangkan pada lahan tambak yang masih terhampar luas, Namun terkendala dalam produksinya secara massal. Langkah percepatan sistem perbenihan perikanan budidaya, KKP telah melakukan berbagai upaya nyata, di antaranya adalah pengembangan broodstock centre. Pengembangan 16 broodstock centre telah disiapkan untuk mengembangkan indukan unggul. Total kapasitas produksi fasilitas pemijahan tersebut mencapai dua miliar ekor indukan per tahun. Selain itu, KKP menggalakkan penggunaan induk ikan unggul dengan semboyan Gerakan Penggunaan Induk Unggul.

Analisis deskriptif terkait dengan faktor pakan ikan menjadi permasalahan krusial dalam akuabisnis budidaya nila, karena memerlukan $70 \%$ dari total biaya operasional. Melalui penyediaan pakan ikan secara mandiri diharapkan dapat menekan biaya pakan, sehingga keuntungan yang diperoleh pembudidaya ikan akan lebih besar dan dapat meningkatkan pendapatan dan kesejahteraan pembudidaya ikan (DPJB, 2017). Target program Gerpari untuk tahun 2019 diharapkan mampu menghasilkan pakan mandiri sejumlah 592.000 ton pakan ikan. Tujuan dari program Gerpari adalah upaya menekan biaya pakan lebih dari $60 \%$ untuk mencapai target produksi perikanan budidaya. Implementasi program Gerpari pada beberapa daerah masih 
terkendala karena masalah teknis dan non teknis. Kendala teknis program Gerpari antara lain di wilayah kabupaten Sleman dan Sungai Gelam, Jambi yaitu keterbatasan input produksi berupa bahan baku dan kontinuitas bahan baku pakan ikan (Rasidi dan Haryadi, 2016). Bahan baku utama pakan ikan adalah tepung ikan yang sebagian besar adalah impor. Produksi tepung ikan pada tahun 2015 mencapai 139.459 ton, dan target yang diharapkan akan mencapai 166.241 ton pada tahun 2016 (DJPB, 2015).

Produksi tepung ikan lokal pada tahun 2008 baru mencapai 33.000 ton/tahun, dan 665.000 ton masih di impor dari berbagai Negara pada tahun 2009. Menurut Rimmer et al. (2013) salah satu faktor kunci dalam pengembangan budidaya perikanan adalah dengan mengembangkan perikanan skala kecil. Penyediaan pakan untuk budidaya ikan skala kecil dan menengah dapat dipenuhi melalui produksi pakan mandiri dengan menggunakan bahan baku lokal yang tersedia pada wilayah masing-masing (Azwar et al., 2011; Azwar et al., 2013). Penggunaan bahan baku lokal perlu ditingkatkan, diharapkan kondisi ini dapat membantu menekan biaya pakan dalam budidaya ikan (Sunarno et al., 2013; Sunarno, 2015). Kendala utama dalam penyediaan bahan baku lokal adalah volume, kontinuitas dan kualitas bahan tersebut. Sehubungan dengan penggunaan bahan baku pakan, yang mengandung unsur fosfor, maka upaya pengendaliannya adalah dengan teknologi jaring ganda pada budidaya ikan di waduk. Teknologi ini cukup efektif dalam mengurangi mengeliminir residu serta memanfaatkan beban unsur nitrogen dan fosfor (Rustadi, 2009).

Data produksi pakan mandiri tercatat 35.000 ton dari 1,3 juta ton kebutuhan pakan ikan secara keseluruhan, artinya kontribusi pakan mandiri baru mencapai 2,7 \%. (KKP, 2015). Kesenjangan yang terjadi pada pemanfaatan bahan baku lokal meliputi empat faktor yaitu: 1). Sebagian bahan baku pakan masih di impor; 2). Pabrik pakan mandiri pada skala rumah - tangga belum berkembang secara optimal; 3). Kenaikan harga ikan konsumsi tidak seimbang dengan kenaikan harga pakan; dan 4). Industri penyediaan bahan baku lokal masih sangat terbatas.

Sehubungan dengan adanya indikasi penyakit pada ikan nila, maka upaya pencegahan merupakan langkah yang tepat untuk pengendalian kasus penyakit pada budidaya ikan. Metode vaksinasi adalah salah satu metode efektif dengan resiko yang minimal. Jenis vaksin koktail bakterin Aeromonas hydrophila dan $A$. agalactiae dapat efektif dalam mencegah penyakit pada ikan (Sumiati et al., 2015).

\section{Kinerja Budidaya Ikan Nila}

Kebijakan pemerintah berupa Inpres no. 7 tahun 2016 menetapkan percepatan industrialisasi perikanan. Program Direktorat Jenderal Perikanan Budidaya-KKP dalam mendukung percepatan industrialisasi perikanan berfokus pada sentra-sentra budidaya dengan komoditas utama. Ikan nila menjadi komoditas utama dengan sentra-sentra budidaya yang telah terbentuk di Jawa, Sumatera, Kalimantan, Sulawesi, dan Bali- Nusa Tenggara. Sentra budidaya nila di dominasi oleh Jawa, Sulawesi dan Sumatera. Komoditas ikan nila menjadi salah satu komoditas utama dalam pembangunan perikanan budidaya dan ditargetkan dapat mendorong tercapainya program industrialisasi perikanan. Target itu ditetapkan berdasarkan keragaan produksi ikan nila yang semakin meningkat dari tahun ke tahun (Gambar 1).

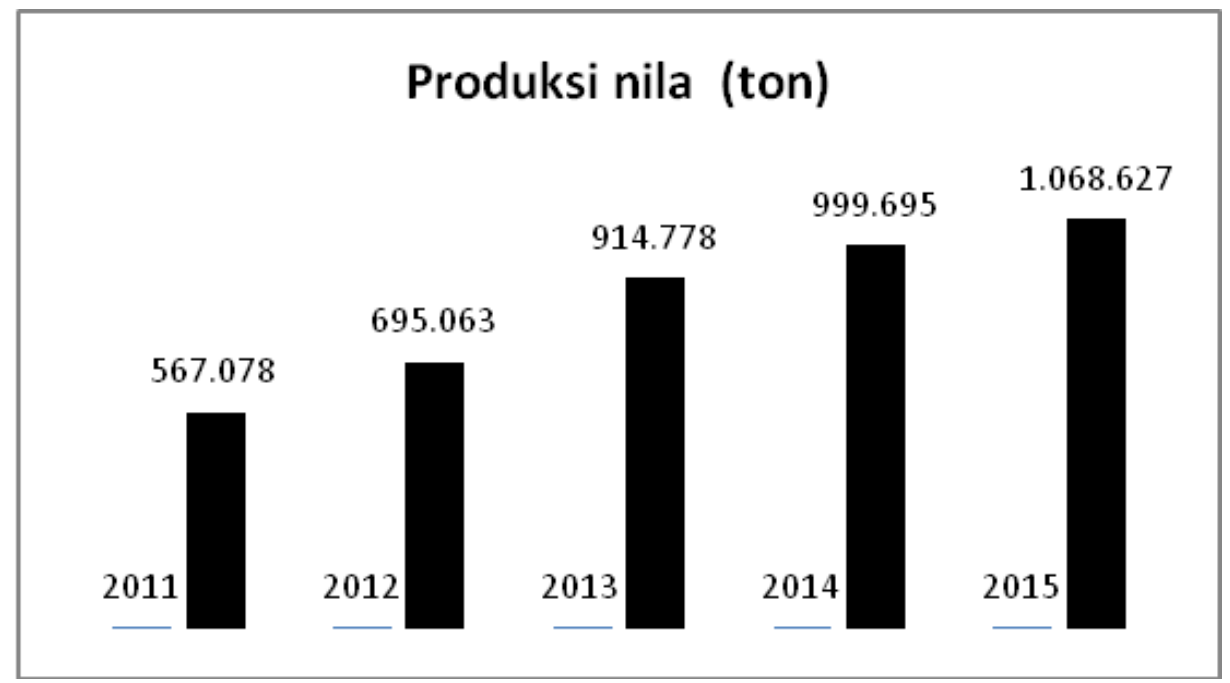

Gambar 1. Perkembangan produksi ikan nila (ton) pada periode $2011-2015$.

Figure 1. Development of tilapia production (tons) in the periode 2011-2015. 
Kontribusi komoditas nila mencapai $30,72 \%$ dari total produksi ikan bersirip di tingkat nasional pada tahun 2015. Capaian produksi dan nilai ekonomi budidaya ikan nila cukup besar kontribusinya pada tingkat nasional (Tabel 1).

Tabel 1. Volume produksi ikan nila (ton) dan kontribusi (\%) dalam perikanan nasional tahun 2015. Table 1. Tilapia production volume (ton) and contribution (\%) in national fisheries in 2015.

\begin{tabular}{lcc}
\hline \multicolumn{1}{c}{ Provinsi } & Volume produksi (ton) & \% Nasional \\
\hline Jawa Barat & 209.655 & 19,61 \\
Sumatera Selatan & 196.841 & 18,41 \\
Sumatera Barat & 139.749 & 13,07 \\
\hline
\end{tabular}

Sumber: DJPB, 2015.

Mengingat kontribusi budidaya ikan nila pada skala nasional, maka dibentuk program Peningkatan Industri Perikanan Nasional (PIPN) terkait dengan komoditas tersebut. Proyeksi peningkatan produksi budidaya ikan nila berkaitan dengan kebutuhan konsumsi berkisar $520-8.148$ ton dan industri mencapai 19.998 ton 313.295 ton dalam periode $2017-2019$ yang akan datang. Sehubungan dengan proyeksi peningkatan produksi budidaya ikan nila, maka kebutuhan benih yang diperlukan akan meningkat dengan kisaran jumlah sebesar 1.084 -2.696 juta ekor pada kurun waktu 2017-2019 (DJPB, 2017).

Target yang merupakan proyeksi peningkatan produksi budidaya nila membutuhkan dukungan pakan yang cukup besar volumenya. Sumber pakan terdiri atas pakan pabrikan dan pakan mandiri yang merupakan produk dari pembudidaya ikan secara kelompok maupun individu. Kebutuhan pakan pada periode 2017 - 2019 di proyeksikan berkisar 73.176 - 181.984 ton untuk pakan mandiri dan 170.743 424.630 ton yang bersumber dari pakan pabrikan. Program PIPN komoditas ikan nila membutuhkan perluasan lahan budidaya yang cukup luas. Kebutuhan lahan untuk ekstensifikasi budidaya nila mencapai $1.016-2.528 \mathrm{Ha}$ dan revitalisasi memerlukan seluas $2.371-5.898 \mathrm{Ha}$ pada periode 2017-2019 (DJPB, 2017).

Analisis deskriptif terkait dengan teknologi budidaya ikan nila pada beberapa sentra budidaya nila ternyata bervariasi dari skala tradisional, tradisional plus, dan skala semi intensif. Ekosistem yang dimanfaatkan untuk budidaya nila juga bervariasi, antara lain budidaya di kolam air tawar, kolam air deras, tambak, waduk dengan menggunakan karamba jaring apung serta karamba tancap di sungai. Potensi budidaya air tawar di Kabupaten Lombok Tengah dapat dijumpai secara merata di semua kecamatan. Luas potensi mencapai $7.721,87 \mathrm{Ha}$ dan tingkat pemanfaatan sebesar 555,73 Ha dengan potensi berupa kolam, perairan umum seperti KJA, keramba sungai dan mina padi. Data produksi ikan nila mencapai $4.115,47$ ton dengan nilai produksi sebesar Rp. 78.193.930 (Dinas Kelautan dan Perikanan, 2016). Perkembangan perikanan budidaya air tawar di Yogyakarta meliputi kabupaten Kulonprogo, Bantul, Gunung Kidul, Sleman, dan wilayah Kota. Produksi ikan nila di dominasi oleh kabupaten Sleman dengan total produksi mencapai $16.994,43$ ton pada tahun 2016. Berbagai program budidaya perikanan di kabupaten Sleman telah mencapai peningkatan produksi yang signifikan. Dalam kurun waktu tahun 2011 - 2016 produksi ikan meningkat sebesar $17,06 \%$ yaitu dari $36.627,00$ ton pada tahun 2015 menjadi 42.875,20 ton pada tahun 2016 (Dinas Pertanian,Perikanan, dan Kehutanan Kabupaten Sleman, 2016). Hasil positif ini dicapai berkat penerapan CBIB yang telah diperoleh sertifikasi kelompok-kelompok pembudidaya ikan sejumlah 36 kelompok.

Provinsi Jawa Barat mempunyai kontribusi terbesar dalam budidaya nila yang mencapai 209.655 ton pada tahun 2015 atau $19.61 \%$ dari total produksi nila secara nasional. Kontribusi terbesar ini dimungkinkan, karena berbagai ekosistem telah digunakan dalam budidaya nila seperti waduk Cirata, waduk Saguling, waduk Jatiluhur, kolam air deras di Subang, kolam air tenang, serta beberapa tambak di Pantura dengan sistem polikultur dengan udang. Ekosistem waduk- waduk tersebut digunakan untuk budidaya nila dengan menggunakan jaring apung. Walaupun sering terjadi up- welling di waduk Cirata yang menyebabkan kematian ikan secara massal, namun usaha budidaya nila masih terus berjalan sampai saat ini. Kasus upwelling sering terjadi akibat pengelolaan pakan yang tidak efisien, sehingga sisa pakan terakumulasi pada dasar perairan. Sub sistem perbenihan ikan nila di Jawa Barat banyak dikerjakan oleh UPR di Cirebon, Purwakarta, Kuningan, Ciamis, Tasikmalaya, Kalijati dan beberapa daerah lainnya. Strain nila unggul Srikandi belum banyak berkembang di wilayah Jawa Barat. Kondisi ini perlu mendapat perhatian, karena permintaan benih nila sebesar 20 juta per bulan belum dapat dipenuhi oleh UPR yang telah eksis. Keunggulan nila Srikandi yang tahan salinitas dan cepat tumbuh dapat menjadi komoditas unggulan untuk di 
budidayakan di tambak guna meningkatkan produksi nila di Jawa Barat.

\section{Analisis Strategi Pengembangan Budidaya Ikan Nila}

Dalam pengembangan budidaya nila , maka lembaga Litbang memiliki peran yang strategis. Identifikasi faktor internal dan eksternal secara sistematis merupakan salah satu metode untuk menggali potensi dan merumuskan strategi yang efektif untuk mengembangkan budidaya perikanan (Badan Litbang, 2011; Rimmer et al, 2013). Selain hal itu sistem pengelolaan yang direncanakan secara matang menjadi salah satu agenda penting untuk keberlanjutan suatu usaha budidaya. Faktor internal dan eksternal budidaya nila diuraikan sebagai berikut ini. Faktor internal yang terdiri atas kekuatan dan kelemahan, dan identifikasi faktor internal hasil estimasi SWOT di tabulasikan pada Tabel 2.

Tabel 2. Matriks analisis faktor-faktor strategi internal budidaya nila

Table 2. Internal Strategic Factors Analysis Summary of tilapia culture

\begin{tabular}{|c|c|c|c|c|}
\hline Faktor-faktor strategi internal & Bobot & Rating & Nilai & Komentar \\
\hline \multicolumn{5}{|l|}{ Kekuatan (strength) } \\
\hline 1.Motivasi yang tinggi & 0,17 & 4 & 0,68 & $\begin{array}{l}\text { Faktor penting yang memengaruhi } \\
\text { kontinuitas produksi. }\end{array}$ \\
\hline 2.Teknologi budidaya telah dikuasai & 0,13 & 3 & 0,39 & $\begin{array}{l}\text { Hasil litbang KP yang telah diadopsi } \\
\text { oleh masyarakat pembudidaya. }\end{array}$ \\
\hline 3.Sarana dan prasarana tersedia & 0,05 & 3 & 0,15 & Sentra2 budidaya nila telah terbentuk \\
\hline 4.Induk nila varietas unggul & 0,15 & 4 & 0,60 & $\begin{array}{l}\text { Hasil Litbang dalam bentuk beberapa } \\
\text { strain unggul nila telah siap pakai } \\
\text { (Srikandi, Nilasa, Nirwana, dll). }\end{array}$ \\
\hline 5.Kontinuitas usaha budidaya & 0,10 & 4 & 0,40 & $\begin{array}{l}\text { Pasar nila yang cukup besar menjamin } \\
\text { kontinuitas usaha nila. }\end{array}$ \\
\hline \multicolumn{5}{|l|}{ Kelemahan (weakness) } \\
\hline $\begin{array}{l}\text { 1. Keterbatasan modal operasional di } \\
\text { tingkat UPR }\end{array}$ & 0,1 & -4 & 0,40 & $\begin{array}{l}\text { Biaya pakan yang tinggi memerlukan } \\
\text { modal cukup besar. }\end{array}$ \\
\hline $\begin{array}{l}\text { 2. Keterbatasan supplai benih ikan } \\
\text { nila unggul, krn belum } \\
\text { berkembangnya industri benih dalam } \\
\text { sistem budidaya ikan. }\end{array}$ & 0,1 & 3 & 0,30 & $\begin{array}{l}\text { Kendala jumlah induk unggul nila. } \\
\text { Usaha perbenihan ikan air tawar belum } \\
\text { berkembang dalam skala industri. } \\
\text { Perbenihan ikan masih dalam skala } \\
\text { kecil di masyarakat. }\end{array}$ \\
\hline $\begin{array}{l}\text { 3. Kelembagaan pokdakan belum } \\
\text { optimal }\end{array}$ & 0,05 & 2 & 0,10 & $\begin{array}{l}\text { Anggota belum semua aktif } \\
\text { berpartisipasi }\end{array}$ \\
\hline $\begin{array}{l}\text { 4. Keterbatasan SDM dan dana } \\
\text { opersional di BBI }\end{array}$ & 0,05 & -2 & 0,10 & $\begin{array}{l}\text { Poduksi benih di BBI belum optimal, } \\
\text { karena keterbatasan biaya operasional. }\end{array}$ \\
\hline $\begin{array}{l}\text { 5. Kebijakan bantuan benih ikan } \\
\text { kepada pembudidaya belum tepat } \\
\text { sasaran }\end{array}$ & 0,10 & -3 & 0,30 & $\begin{array}{l}\text { Bantuan benih yang telah dilakukan } \\
\text { masih bersifat sporadis dan belum dapat } \\
\text { mendorong produksi nila secara } \\
\text { signifikan. }\end{array}$ \\
\hline TOTAL & 1,0 & & 3,32 & \\
\hline
\end{tabular}

Motivasi yang tinggi dari para pembudidaya ikan nila merupakan salah satu kekuatan untuk pengembangan budidaya nila. Hal ini merupakan sesuatu yang penting untuk menjaga kontinuitas produksi ikan nila. Teknologi budidaya yang telah dikuasai oleh para pembudidaya yang sebagian adalah hasil perakitan teknologi dari Puslitbang Perikanan KP, dan jajaran institusi DJPB - KP. Sarana dan prasaran budidaya telah tersedia yang diperlihatkan dengan terbentuknya sentra-sentra budidaya ikan nila pada beberapa daerah. Beberapa strain unggul ikan nila telah dirakit dan secara legal telah diresmikan oleh Menteri KP, antara lain nila Srikandi, nila Nirwana, nila Larasati, dan nila Nilasa. Kontinuitas usaha budidaya nila cukup kuat, mengingat permintaan pasar akan produk nila cukup besar. Namun dari hasil identifikasi menunjukkan bahwa keterbatasan modal operasional di tingkat Unit Perbenihan Rakyat (UPR) menjadi faktor kelemahan yang perlu ditemukan solusinya. Selain hal itu biaya pakan yang tinggi memerlukan modal yang besar, karena $60-70 \%$ biaya operasional adalah biaya pakan. Keterbatasan supply benih ikan nila unggul, karena belum berkembangnya industri benih dalam sistem budidaya ikan. Usaha perbenihan ikan air tawar belum berkembang dalam skala industri. Perbenihan ikan masih dalam skala kecil di masyarakat, meskipun beberapa pabrik pakan telah memproduksi benih ikan yang ditujukan untuk memenuhi kebutuhannya sendiri (Caroline dan Lahindah, 2017). Kelembagaan 
kelompok pembudidaya ikan belum optimal, karena belum semua anggota aktif berpartisipasi secara penuh. Keberadaan BBI milik pemerintah belum dapat memberikan kontribusi seperti yang dibutuhkan oleh masyarakat, karena keterbatasan sarana, biaya dan
SDM. Kebijakan bantuan benih ikan kepada pembudidaya belum tepat sasaran. Bantuan benih yang telah dilakukan masih bersifat sporadis dan belum dapat mendorong produksi nila secara signifikan (Tabel 3).

Tabel 3. Matriks analisis faktor-faktor strategi eksternal budidaya nila Table 3. External Strategic Factors Analysis Summary of tilapia aquculture

\begin{tabular}{|c|c|c|c|c|}
\hline $\begin{array}{l}\text { Faktor-faktor strategi } \\
\text { eksternal }\end{array}$ & Bobot & Rating & Nilai & Komentar \\
\hline \multicolumn{5}{|l|}{ Peluang (opportunities) } \\
\hline $\begin{array}{l}\text { 1.Permintaan produk tinggi, stok } \\
\text { terbatas }\end{array}$ & 0,20 & 4 & 0,80 & $\begin{array}{l}\text { Kebutuhan nila konsumsi relatif tinggi, karena } \\
\text { sebagian besar untuk di ekspor. }\end{array}$ \\
\hline 2. Potensi usaha pola kemitraan & 0,10 & 3 & 0,30 & Modal pembudidaya terbatas. \\
\hline $\begin{array}{l}\text { 3.Potensi kenaikan harga benih } \\
\text { nila }\end{array}$ & 0,05 & 3 & 0,15 & Peluang peningkatan produksi benih \\
\hline 4.Program bantuan pemerintah & 0,05 & 2 & & $\begin{array}{l}\text { Bantuan pemerintah berupa teknologi, induk, } \\
\text { sarana prasarana. }\end{array}$ \\
\hline $\begin{array}{l}\text { 5. Diversifikasi komoditas } \\
\text { budidaya di tambak }\end{array}$ & 0,05 & 2 & 0,10 & Potensi tambak idle untuk budidaya nila. \\
\hline $\begin{array}{l}\text { 6. BBI Sentral sebagai produsen } \\
\text { benih nila unggul untuk di } \\
\text { distribusikan kepada } \\
\text { pembudidaya }\end{array}$ & 0,05 & 3 & 0,15 & $\begin{array}{l}\text { Optimasi produksi benih nila dengan } \\
\text { dukungan APBD. }\end{array}$ \\
\hline \multicolumn{5}{|l|}{ Tantangan (threath) } \\
\hline $\begin{array}{l}\text { 1.Pengaruh limbah terhadap } \\
\text { lingkungan }\end{array}$ & 0,05 & -2 & $-0,10$ & $\begin{array}{l}\text { Pengadaan instalasi pengolahan limbah } \\
\text { diperlukan. }\end{array}$ \\
\hline 2.Produk pesaing & 0,15 & -2 & $-0,30$ & Produsen utama nila dunia: Cina, dan India. \\
\hline $\begin{array}{l}\text { 3. Biaya pakan yang semakin } \\
\text { meningkat. }\end{array}$ & 0,18 & -4 & $-0,72$ & $\begin{array}{l}\text { Formulasi pakan mandiri layak } \\
\text { dipertimbangkan. }\end{array}$ \\
\hline $\begin{array}{l}\text { 4. Kebijakan provinsi dengan } \\
\text { kabupaten tidak sinergis. }\end{array}$ & 0,07 & -3 & $-0,21$ & $\begin{array}{l}\text { Provinsi punya kebijakan sendiri untuk } \\
\text { menentukan jenis ikan yang dikembangkan }\end{array}$ \\
\hline $\begin{array}{l}\text { 5. Diversifikasi produk pada nila } \\
\text { konsumsi. }\end{array}$ & 0,05 & 3 & 0,15 & $\begin{array}{l}\text { Konsumen dalam negeri lebih menyukai ikan } \\
\text { nila hidup dibandingkan dengan nila olahan. }\end{array}$ \\
\hline TOTAL & 1,0 & & 0,32 & \\
\hline
\end{tabular}

Peluang bagi budidaya ikan nila adalah permintaan produk nila relatif tinggi, namun stok terbatas. Potensi pasar nila di pasar global masih terbuka luas, terutama pasar Amerika yang merupakan pasar yang cukup besar (Fitzsimmons, 2012; FAO, 2017). Potensi usaha pola kemitraan antara pembudidaya dengan pihak pabrik pakan, hal ini diharapkan dapat meningkatkan produksi budidaya nila. Pola kerjasama semacam ini antara lain telah diterapkan di kabupaten Lombok Tengah yang secara positif dapat meningkatkan produksi ikan nila di wilayah tersebut. Potensi kenaikan harga benih nila yang telah terjadi di beberapa daerah, kondisi ini mampu mendorong peningkatan produksi benih nila, meskipun belum sepenuhnya dapat menghasilkan produk benih nila unggul. Program bantuan pemerintah merupakan peluang bagi pembudidaya nila untuk mengembangkan usahanya. Bantuan pemerintah Pusat diberikan berupa bimbingan teknologi, bantuan modal, induk nila, peralatan pembuatan pakan mandiri yang dikemas dalam program Gerpari, gerakan induk unggul dan program bantuan dari Pemerintah Daerah. Diversifikasi komoditas budidaya di tambak. Jenis ikan nila strain Srikandi dapat dibudidayakan di lahan tambak. Potensi tambak merupakan peluang untuk meningkatkan produksi nila secara signifikan. Beberapa daerah telah mulai mengembangkan budidaya nila di tambak, namun teknik budidaya ini belum diaplikasikan secara meluas di masyarakat. BBI Sentral sebagai produsen benih nila unggul untuk didistribusikan kepada pembudidaya telah eksis. Meskipun belum optimal dalam menghasilkan benih nila unggul dalam jumlah yang mencukupi kebutuhan masyarakat. 
Tantangan yang masih dihadapi pada budidaya nila antara lain adalah pengaruh limbah terhadap lingkungan budidaya ikan nila merupakan tantangan yang tidak mudah dihadapi. Keterbatasan sumber air yang memenuhi persyaratan tehnis memerlukan solusi yang tepat, agar produksi nila masih dapat berjalan dengan baik. Teknologi budidaya yang efektif dan efisien menjadi salah satu solusi untuk menghadapi polusi lingkungan budidaya. Produk pesaing dalam budidaya nila menjadi bahan pertimbangan penting, agar dapat dihasilkan produk yang berkualitas dan kuantitas yang cukup besar untuk memenuhi permintaan pasar domestik dan eskpor. Produsen utama nila dunia yaitu Cina, dan India, merupakan pesaing utama di pasar global (FAO, 2017). Produsen terbesar nila saat ini adalah Negara Cina dan India menduduki peringkat ke dua. Biaya pakan yang semakin meningkat memerlukan solusi yang tepat, meskipun telah dibentuk program Gerpari. Namun program ini belum memberikan dampak yang signifikan untuk mendorong peningkatan produksi nila pada tingkat nasional. Kebijakan provinsi dengan kabupaten terkadang kurang sinergis. Provinsi mempunyai kebijakan sendiri untuk menentukan jenis ikan yang perlu dikembangkan di wilayah tertentu. Oleh karena itu kebijakan yang sinergis menjadi solusi untuk mengembangkan budidaya ikan nila (Mariza et al., 2016). Diversifikasi produk pada nila konsumsi merupakan tantangan ekonomi yang cukup penting. Konsumen dalam negeri lebih menyukai ikan nila hidup dibandingkan dengan nila olahan. Promosi gerakan makan ikan olahan telah dirintis cukup lama, namun pola konsumen dalam negeri belum bergeser pula.

\section{Kebijakan Strategis Pengembangan Budidaya Nila Berdaya Saing}

Matriks untuk penentuan strategi pengembangan budidaya nila berdaya saing dapat dilihat pada Tabel 4 .

Tabel 4. Matrix SWOT pengembangan budidaya nila Table 4. SWOT Matrix of tilapia culture development

\begin{tabular}{|c|c|c|}
\hline FAKTOR INTERNAL & $\begin{array}{l}\text { KEKUATAN ( strength ) } \\
\text { 1.Motivasi yang tinggi pada } \\
\text { pembudidaya. } \\
\text { 2.Teknologi budidaya nila telah dikuasai. } \\
\text { 3. Sarana dan prasarana tersedia } \\
\text { 4. Induk nila varietas unggul } \\
\text { 5.Kontinuitas usaha }\end{array}$ & $\begin{array}{l}\text { KELEMAHAN (weakness) } \\
\text { 1.Keterbatasan modal operasional } \\
\text { di tingkat UPR } \\
\text { 2. Keterbatasan supplai benih ikan } \\
\text { nila unggul, krn belum } \\
\text { berkembangnya industri benih } \\
\text { dalam sistem budidaya ikan. } \\
\text { 3. Kelembagaan pokdakan belum } \\
\text { optimal } \\
\text { 4. Keterbatasan SDM dan dana } \\
\text { opersional di BBI } \\
\text { 5. Kebijakan bantuan benih ikan } \\
\text { kepada pembudidaya belum tepat } \\
\text { sasaran }\end{array}$ \\
\hline $\begin{array}{l}\text { PELUANG (opportunities) } \\
\text { 1.Permintaan produk tinggi, stok terbatas } \\
\text { 2. Potensi usaha pola kemitraan } \\
\text { 3.Potensi kenaikan harga benih nila } \\
\text { 4.Program bantuan pemerintah } \\
\text { 5. Diversifikasi komoditas budidaya di } \\
\text { tambak } \\
\text { 6. BBI Sentral sebagai produsen benih } \\
\text { nila unggul utk didistribusikan kepada } \\
\text { pembudidaya }\end{array}$ & $\begin{array}{l}\text { Strategi SO (strength opportunities) } \\
\text { 1. Efisiensi teknik budidaya nila unggul } \\
\text { secara intensif untuk mencapai kuota } \\
\text { ekspor. } \\
\text { 2. Pemanfaatan tambak darat dengan } \\
\text { salinitas kurang dari } 15 \% \text {, dan sawah } \\
\text { tambak di Lamongan, Jawa Timur. } \\
\text { 3. Produksi massal induk nila unggul } \\
\text { oleh broodstock center yg telah } \\
\text { operasional. }\end{array}$ & $\begin{array}{l}\text { Strategi WO (weakness } \\
\text { opportunities) } \\
\text { 1. Fasilitasi produksi massal benih } \\
\text { nila unggul oleh BBI sentral, UPR, } \\
\text { dan swasta. Terutama di lokasi yg } \\
\text { terkait dg program PIPN (Sulawesi } \\
\text { utara, NTB, Jawa barat, Sumatera } \\
\text { selatan). } \\
\text { 2. Monitoring dan evaluasi } \\
\text { produksi budidaya nila per } \\
\text { semester oleh Dit.Produksi dan } \\
\text { Usaha Budidaya, DJPB. }\end{array}$ \\
\hline $\begin{array}{l}\text { Tantangan (threath) } \\
\text { 1.Pengaruh limbah thd lingkungan } \\
\text { 2.Produk pesaing } \\
\text { 3. Biaya pakan yang semakin meningkat } \\
\text { 4. Kebijakan provinsi dengan kabupaten } \\
\text { tidak sinergis. } \\
\text { 5. Diversifikasi produk pada nila } \\
\text { konsumsi. }\end{array}$ & $\begin{array}{l}\text { Strategi ST ( strength threat) } \\
\text { 1. Efisiensi biaya operasional utk } \\
\text { menghasilkan produk ikan nila berdaya } \\
\text { saing, melalui manajemen pakan yg lebih } \\
\text { efisien. } \\
\text { 2. Sinkronisasi kebijakan Pusat dan } \\
\text { Daerah terkait penentuan komoditas } \\
\text { unggulan daerah sentra budidaya. } \\
\text { 3. Perluasan program Gerpari dgn } \\
\text { pembentukan industri bahan baku lokal di } \\
\text { sentra budidaya nila (Jawa Barat, } \\
\text { Sumatera Selatan, Sumatera Barat). } \\
\text { 4. Monitoring dan evaluasi produksi } \\
\text { pakan mandiri per semester oleh } \\
\text { Dit.Pakan dan Obat lkan, DJPB. }\end{array}$ & $\begin{array}{l}\text { Strategi WT (weakness threath ) } \\
\text { Pembangunan industri perbenihan } \\
\text { ikan nila di kawasan Indonesia } \\
\text { Timur dan Tengah yang potensial. }\end{array}$ \\
\hline
\end{tabular}


Hasil analisis SWOT menunjukkan bahwa dalam upaya pengembangan budidaya nila berdaya saing terdapat empat strategi yaitu: (1). Strategi SO; (2). Strategi WO; (3) Strategi ST; dan (4) Strategi WT (Tabel 4).

Srategi WO: keterbatasan kuantitas benih nila unggul merupakan kendala yang perlu mendapat perhatian serius dari pemerintah. Strategi produksi massal nila unggul pada BBI sentral, UPRUPR, dan hatchery milik swasta perlu mempunyai fasilitas yang optimal, terutama pada lokasi-lokasi yang berada dalam program peningkatan produksi ikan nasional seperti di Sulawesi Utara, NTB, Jawa Barat dan Sumatera Selatan.

Strategi ST: strategi perluasan program Gerpari dengan pembentukan industri bahan baku lokal di sentra budidaya nila (Jawa Barat, Sumatera Selatan, Sumatera Barat) perlu diupayakan implementasinya secara lebih konsisten. Efisiensi manajemen pakan ikan nila perlu ditingkatkan untuk menghasilkan produk nila yang berdaya saing tinggi.

Strategi WT: Strategi pembangunan industri perbenihan ikan nila perlu di implementasikan di kawasan budidaya potensial pada wilayah Indonesia Timur dan Indonesia Tengah.

Dari hasil analisis SWOT ternyata posisi budidaya nila berada pada kuadran satu dengan koordinat $(6,43$; $0,20)$, posisi ini mengartikan bahwa budidaya ikan nila ini berada pada situasi yang sangat menguntungkan. Usaha budidaya nila mempunyai peluang dan kekuatan sehingga dapat memanfaatkan peluang yang ada. Strategi yang harus diterapkan dalam kondisi ini adalah mendukung kebijakan pertumbuhan yang agresif (Grand oriented strategy).

Strategi SO pada komoditas nila yaitu dengan memanfaatkan tambak darat sebagai upaya perluasan lahan budidaya selain kolam dan KJA yang telah eksis. Selain itu efisiensi tehnik pada budidaya nila unggul seperti nila Srikandi, nila Nirwana dan Nilasa menjadi kebutuhan mendesak untuk mencapai produktivitas yang tinggi. Kebutuhan induk unggul nila dapat di produksi secara massal melalui beberapa brodstock center milik pemerintah maupun perusahaan swasta yang telah operasional.

\section{KESIMPULAN DAN REKOMENDASI Kesimpulan}

Program percepatan industrialisasi perikanan membutuhkan dukungan tehnis, anggaran dan kebijakan. Ikan nila yang merupakan salah satu komoditas utama memiliki peluang besar mengingat pasar domestik dan global yang masih terbuka luas. Usaha budidaya nila mempunyai peluang dan kekuatan sehingga dapat memanfaatkan peluang yang ada. Strategi yang harus diterapkan dalam kondisi ini adalah mendukung kebijakan pertumbuhan yang agresif (Grand oriented strategy). Strategi jangka pendek adalah penerapan tehnik budidaya yang efisien komoditas nila unggul seperti nila Srikandi, nila Nirwana dan Nilasa menjadi kebutuhan mendesak untuk mencapai produktivitas yang tinggi. Strategi jangka menengah adalah pemanfaatan tambak darat dengan komoditas nila di lahan tambak darat sebagai upaya perluasan lahan budidaya selain kolam dan karamba jaring apung yang telah eksis. Kebutuhan induk unggul nila dapat di produksi secara massal melalui beberapa brodstock center milik pemerintah maupun perusahaan swasta yang telah beroperasi.

\section{Rekomendasi Kebijakan}

Antisipasi kebijakan dalam merespon Inpres No.7 Tahun 2016 adalah pengembangan industri pakan ikan skala kecil dan industri perbenihan melalui pemanfaatan induk unggul dalam perspektif pertumbuhan dan perluasan yang mencakup dua aspek kebijakan sebagai berikut: (a) Pengembangan produksi berbasis potensi pasar yang dikomplemen dengan perbaikan sistem budidaya ikan nila; dan (b) Pengembangan inovasi kelembagaan dan sistem insentif dalam mendukung ketersediaan dan akses sarana produksi utama pada usaha budidaya nila skala kecil.

Dalam jangka menengah pemerintah agar fokus pada pengembangan industri perbenihan ikan dengan memanfaatkan induk unggul, serta pengembangan pakan mandiri pada usaha budidaya nila skala kecil. Program prioritas yang perlu dipertimbangkan adalah swasembada benih ikan, peningkatan daya saing produk perikanan, dan peningkatan efektivitas program Gerpari, serta GAUL bagi pembudidaya skala kecil. Upaya tersebut, perlu dikomplemen dengan program jangka panjang yang mencakup program adaptasi teknologi budidaya ikan terhadap perubahan lingkungan perairan, sehingga perikanan budidaya tetap berkelanjutan. 


\section{PERSANTUNAN}

Terima kasih kami haturkan kepada Kepala Pusat Riset Perikanan yang telah memberikan dana APBN T.A 2017 untuk membiayai penelitian ini. Demikian pula kami haturkan ucapan terima kasih kepada Bp. Prof.Dr. I Wayan Rusastra, pakar kebijakan di Forum Komunikasi Profesor Riset Pertanian, yang telah memberikan saran dan masukan yang sangat berharga bagi penelitian ini.

\section{DAFTAR PUSTAKA}

Azwar, Z.I., Praseno, O., Kristanto, A.H., Erlania., \& Heptarina, D. (2011). Kebutuhan pakan dan kebijakan industri pakan dalam menunjang usaha budidaya perikanan. Analisis Kebijakan Pembangunan Perikanan Budidaya. Pusat Penelitian dan Pengembangan Perikanan Budidaya. ( p.1-13). Jakarta.

Azwar, Z.I., Insan, I., Samsudin, R., \& Heptarina, D. (2013). Strategi dan kebijakan pegembangan industri bahan baku pakan untuk menunjang pakan ekonomis di daerah pengembangan ikan patin. Analisis Kebijakan Pembangunan Perikanan Budidaya. (p. 119 - 129). Pusat Penelitian dan Pengembangan Perikanan Budidaya. Jakarta.

Badan Penelitian dan Pengembangan Pertanian. (2011). Road map: strategi pertanian menghadapi perubahan iklim (Revisi) (p. 64). Badan Penelitian dan Pengembangan Pertanian. Kementerian Pertanian. Jakarta.

Caroline, \& Lahindah, L. (2017). Analisa dan usulan strategi pemasaran dengan metode analisa SWOT (Studi kasus pada UMKM pakan ikan Waringin Bandung). Jurnal Manajemen Indonesia, 17(2), 35 -45 .

Dinas Pertanian, Perikanan, dan Kehutanan. (2016). Profil perikanan sleman tahun 2016. (p.1-22). Kabupaten Sleman.

Direktorat Jenderal Perikanan Budidaya. (2015). Rancangan rencana strategis Direktorat Jenderal Perikanan Budidaya 2015 - 2019. (38 p). Kementerian Kelautan dan Perikanan.Jakarta.

Direktorat Jenderal Perikanan Budidaya. (2017). Kelompok kerja peningkatan produksi perikanan. Direktorat Kawasan dan Kesehatan Ikan. Direktorat Jenderal Perikanan Budidaya. (62 pp). Kementerian Kelautan dan Perikanan. Jakarta.
Dinas Perikanan dan Kelautan. (2016). Profil dislutkan Lombok Tengah. (30pp). Kabupaten Lombok Tengah.

F.A.O. (2017). International demand for tilapia steady, though US market weak with discouraging prices. GLOBEFISH-Analysis and information of world fish trade.http://www.fao.org/in-action/globefish/ market-report/resource-detail/en/c/107669.

Fitzsimmons, K. (2012). The success story of tilapia industry; current and future trends of the US sea food market. Nong Lam University - Ho Chi Minh. Vietnam presentation in 28 June 2012.

Kementerian Kelautan dan Perikanan. (2015). Peraturan Menteri Kelautan dan Perikanan No.25 tentang Renstra 2015 - 2019. Biro Hukum. KKP. Jakarta.

Kementerian Kelautan dan Perikanan. (2016). Informasi Kelautan dan Perikanan Bulan Januari 2016. No.01/PUSDATIN.

KementerianPPN/Bappenas. (2016). Kajian Strategi Industrialisasi Perikanan untuk Mendukung Ekonomi Wilayah. Direktorat Kelautan dan Perikanan. (22pp) Kedeputian Bidang Maritim dan Sumber Daya Alam. Jakarta.

Mariza, N., Wicaksono, B. \& Octavia, J. (2016). Kebijakan percepatan pembangunan industri perikanan. Center for Public Policy Transformation. (6 pp).Jakarta.

Marimin. (2004). Teknik dan aplikasi pengambilan keputusan kriteria majemuk (p.197). Grasindo. Jakarta.

Mulyaningrum. 2018. Metode dan teknik pendekatan partisipatif RRA (Rapid Rural Appraisal) PRA (Participation Rural Appraisal). (23 pp). Materi Pelatihan Pembantu Peneliti. Universitas Pasundan.

Pusat Data Statistik dan Informasi. (2016). Informasi Kelautan dan Perikanan. Bulan Januari No. 01/ PUSDATIN 1/2016. (26 pp).Kementerian Kelautan dan Perikanan. Jakarta.

Pusat Data. (2016). Instruksi Presiden Republik Indonesia Nomor 7 Tahun 2016 tentang Percepatan Industrialisasi Perikanan Nasional. http:// www.hukumonline.com/pusatdata. 
Rangkuti, F. (2008). Analisis SWOT teknik membedahkasus bisnis. Reorientasi Konsep Perencanaan Strategis untuk Menghadapi Abad 21. (p. 1-47) PT. Gramedia Pustaka Utama. Jakarta.

Rasidi \& Haryadi, J. (2016). Evaluasi kebijakan pakan mandiri. Prosiding Forum Inovasi Teknologi. (p. 689-702). Puslitbang Perikanan Budidaya. Jakarta.

Rimmer, M.A., Sugama, K., Rakhmawati, D., Rofiq, R., \& Habgood, R.H. (2013). A Review and SWOT analysis of aquaculture development in Indonesia. Reviews in Aquaculture (2013), 5, 215 - 279.

Rustadi. (2009). Eutrofikasi nitrogen dan fosfor serta pengendaliannnya dengan perikanan di Waduk Sermo. Jurnal Manusia dan Lingkungan, 16(3), 176 -186 .

Sunarno, M.T.D., Sulhi, M., \& Suryaningrum, L.H. (2013). Kajian pabrik pakan ikan lokal dalam mendukung industrialisasi budidaya Patin
(Pangasius sp.) di Kabupaten Kampar Provinsi Riau.(p.371-379). Prosiding Forum Inovasi Teknologi. Puslitbang Perikanan Budidaya. Jakarta.

Sunarno,M.T.D.(2015). Peluang dan tantangan pengembangan pakan mandiri. Makalah disampaikan pada Forum Group Discussion pakan Mandiri. Pusat Penelitian dan Pengembangan Perikanan Budidaya.

Sumiati, T., Sukenda., S. Nuryati., A.M. Lusiastuti. (2015). Pengembangan metode elisa untuk mendeteksi imun spesifik pada ikan nila (Oreochromis niloticus) yang Divaksinasi terhadap Aeromomas hydrophila dan Streptococcus agalactiae. Jurnal Riset Akuakultur, 10(2), 243250.

Townsley. (1996). Rapid rural appraisal, participatory rural appraisal and aquaculture. FAO Fisheries Technical Paper (No. 358. 109 pp). FAO of the UN, Rome. 